\title{
Nutritional Diversity Assessment in Chickpea-A Prospect for Nutrient Deprived World
}

\author{
Abdullah KAHRAMAN ${ }^{1 *}$, Anamika PANDEY ${ }^{2}$, Mohd. Kamran KHAN ${ }^{2}$ \\ ${ }^{1}$ Harran University, Faculty of Agriculture, Department of Field Crops, Sanliurfa 63040, Turkey \\ [ORCID ID: http://orcid.org/ 0000-0002-8829-3797] \\ ${ }^{2}$ Selcuk University, Faculty of Agriculture, Department of Soil Science and Plant Nutrition, Konya 42079, \\ Turkey [ORCID ID: http://orcid.org/0000-0002-5022-8359 (A. PANDEY), 0000-0003-0437-4416 \\ (M.K.KHAN)] \\ *Corresponding author: kahraman@harran.edu.tr
}

\begin{abstract}
In developing countries, grain legumes are next to cereals in human food dealing with the hunger and malnutrition. Chickpea (Cicer arietinum L.) is the nutritious legume crop providing ample amount of proteins, nutrients and vital amino acids to human body. The aim of this mini-review is to provide an overview of the benefits of biofortification of Chickpea crop and nutritional diversity studies on Chickpea conducted so far to strengthen the biofortification process.
\end{abstract}

Key Words: Biofortification, Cicer arietinum (L.), Iron, Mineral micronutrients, Nutrition

\section{Nohutta Besinsel Çeşitlilik Değerlendirmesi - Yetersiz Beslenme Sorunu Yaşayan Dünyamız Için Bir Arayış}

Öz

Gelişmekte olan ülkelerde, tane baklagiller açlık ve yetersiz beslenmeyi giderme konusunda tahıllarla yan yana yer almaktadır. Nohut (Cicer arietinum L.) besleyici değeri yüksek bir baklagil bitkisi olup insan vücudu için yeterli miktarda protein, besin elementleri ve temel amino asitleri sağlamaktadır. Bu kısa derlemenin amacı, biyofortifikasyonu güçlendirmek için nohut bitkisinde biyofortifikasyonun yararları ve besinsel çeşitlilik konusunda günümüze kadar yapılan çalışmaları değerlendirmede genel bir bakış açısı sağlamaktır.

Anahtar Kelimeler: Biyofortifikasyon, Cicer arietinum (L.), Demir, Mineral mikro besin maddeleri, Beslenme

\section{Introduction}

The global population is increasing at an alarming speed and projected to go beyond nine billion by 2050 (Godfray, 2010). This rapid rise in population posed a severe threat to the food and nutritional security of human beings. Consequently, dietary intake of more than half of the human population lacks in crucial mineral elements and proteins (White and Broadley, 2009). As a result, malnutrition has evolved as a major challenge towards billions of people worldwide leading to more than 20 million deaths every year (Bouis and Welch, 2010). Not only, developing countries in Asian, African and Latin American zones are suffering from this disaster due to unequal 
distribution of food and limited resources (Kennedy et al., 2003; FAO, 2015); but western world including North America and Europe are also influenced by it due to dysfunctional food habits (Combs et al., 1998; Sadanandan and Channarayappa, 2014).

Although more than 22 minerals are required for the physiological development of the human body, deficiency of micronutrients has the most devastating impact on the human health affecting beyond 30\% people worldwide (WHO, 2000; Welch, 2002; Welch and Graham, 2004; White and Broadley, 2005; Nestelet al., 2006; Tulchinsky, 2010; Thavarajah and Thavarajah, 2012). It has been assessed that over 3 billion people are being suffered with iron deficiency particularly women and school children (Bohra et al, 2015). Moreover, evaluations indicate that around one-third of the world population is Zinc deficient, widespread in countries with $\mathrm{Zn}$ deficient soils like China, India, Iran, Pakistan and Turkey (Hotz et al., 2004; Cakmak, 2008).

Besides micronutrients deficiencies, protein energy malnutrition is also a prevalent issue that needs to be addressed effectively. Although it is more prominent in children, especially of developing countries, adults are also largely afflicted by the disorder (Monti and Grillo, 1983; Haider and Haider, 1984; Duranti and Gius, 1997; World Health Organization (WHO), 2013). These nutritional deficiencies evolved due to dearth of good quality and balanced food, its expensiveness, unawareness of its nutritional value and inadequate agricultural methods based on the renovation of only major nutrients (Niba, 2003; Sadanandan and Chanaryappa, 2014). To address the evolving malnutrition across the world, several traditional approaches including supplementation and food fortification have been implemented (Welch and Graham, 2004; White and Broadly, 2005, Rana et al., 2012). However, these strategies are greatly restricted due to high consumer cost and various social and cultural constraints (White and Broadly, 2009). In such state, biofortification is considered as a potential solution to combat global malnutrition.

\section{Biofortification}

Biofortification is one of the most economical methods to develop nutrient rich crops and combat global nutrient deficiency (Welch and Graham, 2004; White and Broadley, 2005).In this process, nutrient concentration and bioavailability is increased by employing agronomic and genetic biofortification techniques. It permits the cultivation of nutrient rich varieties without declining its yield (Nestel et al., 2006). Agronomic biofortification deals with the application of fertilizer to improve the soil fertility, while genetic biofortification relies on conventional breeding and transgenic methods (Harvestplus, 2012; Hoekenga, 2014). Although majority of biofortification efforts has been made towards micronutrient and vitamins enrichment of crops, fewer studies have been conducted for protein enrichment (Welch, 1999). Agronomic biofortification requires consistent application of fertilizers making it a pricy strategy that is also hazardous to the environment (Carvalho and Vasconcelos, 2013). Biofortification through conventional breeding is a cost efficient and sustainable method as compared to agronomic biofortification, although a wide range of diversity is a prerequisite to introgressa particular character; and prolonged duration is required to develop the trait. 
Biofortification by genetic engineering is a quick and competent method to improve the nutrient quality of the crops (Mayer et al., 2008). Several research studies presented that grain legumes have become a major alternative crop to fulfill the nutritional requirements of the people who are basically dependent on carbohydrate rich cereals (Graham et al., 2001). Additionally, high content of nutrients in legumes compared to cereals and their capability of nitrogen fixation make them valuable attractive crops for biofortification (Iqbal et al., 2006; White and Broadley, 2009; Bohra et al., 2015).

\section{Chickpea- A Potential Crop for Biofortification}

Chickpea is one of the most significant legume crops inherently loaded with proteins, vitamins and minerals, but still with a great prospect to enhance the nutritional value. Although it is basically grown in arid and semiarid climatic conditions, it has potential to develop in an extensive range of growth environments and support the agriculture system worldwide. Moreover, it lessens the damaging effects of farming practices on the environment by fixing the atmospheric nitrogen and refining the soil fertility (Sahin and Gecit, 2006, Caliskan et al., 2013).

It is a chief source of protein for resourcepoor people mostly in developing countries that are dependent on plant proteins to fulfill their dietary needs and hence, its global demand is continuously rising. It has ample amount of oil and protein content as compared to cereals and thus, capable of supplementing the cereals based menu of a major population (Tonk et al., 2010). Carbohydrates and proteins are the major components of chickpea collectively responsible for $80 \%$ of its dry weight (Jukanti et al., 2012). An average of $4.1 \mathrm{mg}$ zinc, $5 \mathrm{mg}$ iron, $138 \mathrm{mg}$ magnesium, $160 \mathrm{mg}$ calcium and 334-446 Kcal per $100 \mathrm{~g}$ seeds contribute to most of the health benefits of chickpea (Petterson et al., 1997; Wood and Grusak, 2006; Jukanti et al., 2012; Ray et al., 2014). Moreover, richness of chickpea in dietary fibres, vitamins, starch, sugars, lipids and unsaturated fatty acids make it a functional food source (Chavan et al., 1989). Thus, in the growing world, biofortification of chickpea may offer great potential to alleviate malnutrition and develop sustainable agriculture.

Genetic Diversity in nutritional profile of Chickpea-An important aspect for Breeding

Assessment of genetic variability in existing chickpea gene pool for nutrient and protein content is one of the competent methods to identify potential genotypes for breeding strategy (Dwivedi et al., 2012). Although several efforts have been made to estimate the genetic variability of chickpea genotypes, still detailed studies are required to understand the adaptable range of different nutrients for genetic biofortification programs.

In 1998, Ibanez et al. estimated the genetic variability in mineral composition of 16 Desi and 21 Kabuli Chickpea cultivars grown under identical environmental agricultural conditions, hence, eliminating the genotype environment interaction effect. They obtained 1.22, 4.48, 3.53, 1.68, and $21.9 \mathrm{mg} / 100 \mathrm{~g}$ of mean copper, iron, zinc, manganese and sodium content, respectively. In their analysis, Kabuli and Desi chickpea biotypes showed similar Zn, $\mathrm{Fe}, \mathrm{Cu}, \mathrm{Mn}$ and Nacontents. Though, $\mathrm{Ca}$ and $\mathrm{Mg}$ content in Desi biotypes were higher than Kabuli ones, $\mathrm{K}$ content was significantly 
lower. Their results were in contrast with a previous study conducted by Singh and Jambunathan, (1981) who found no difference in the mean element concentrations of eight Desi and seven Kabuli cultivars. It shows that nutrient composition not only depends on the biotypes, but also on the choice of cultivars.

Ereifej et al., 2001 evaluated the nutrient composition of three developed and one commercial Jordanian chickpea cultivars and found significant variation in protein and mineral content. They emphasized on the cumulative effect of the genotype and growing season on the measured characters. Besides seeds, ibrikci et al (2003) revealed significant variation in mineral concentrations of young leaves of 19 kabuli and desi chickpea accessions. They observed variability of 1.3-1.8 times and 1.5-2.4 times in macronutrient and micronutrient content, respectively, although there were no huge variances in leaf mineral values of kabuli and desi genotypes. Zia-Ul-Haq, (2007) determined a range of 3.5-6.0 mg per $100 \mathrm{~g}$ $\mathrm{Zn}$ and 2.4-4.1 mg per $100 \mathrm{~g}$ Fe in seeds of four desi chickpea cultivars. In a study, Ozer et al., 2010 examined the diversity of 91 Turkish Kabuli chickpea landraces grown under same agroclimatic conditions for several nutritional and physicochemical properties. They revealed great variation in seed protein content of landraces ranging from 17.5 to $25.3 \%$.

Bueckert et al., 2011 screened 10 Canadian chickpea genotypes (4 kabuli and 6 desi types) for the estimation of iron, zinc, calcium and magnesium concentrations grown at two high-yielding locations in Canada in two different years. They found higher zinc, similar iron, and lesser magnesium and calcium concentrations in kabuli genotypes as compared to desi genotypes. Moreover, they estimated a positive association of calcium and iron content with phytic acid, a chickpea constituent responsible for bioavailability of nutrients. For the first time, Thavarajah and Thavarajah, 2012 reported the nutrient content and bioavailability of commercially grown USA chickpea genotypes to support the biofortification programs. They found a range of 3.7-7.4 $\mathrm{mg} / 100 \mathrm{~g}$ Zinc, 4.6-6.7 $\mathrm{mg} / 100 \mathrm{~g}$ Iron,0.7-1.1 mg/100 g Copper, 15.3-56.3 $\mu \mathrm{g} / 100 \mathrm{~g}$ Selenium, 2627-3703 $\mathrm{mg} / \mathrm{kg}$ Phosphorus, 93.4-197.4 mg/100 g Calcium, 125.1-158.7 mg/100 g Magnesium and $732.2-1125.5 \mathrm{mg} / 100 \mathrm{~g}$ Potassium in their study; and revealed potential mineral bioavailability of chickpea genotypes.

In 2014, Ray et al., estimated the nutrient range of eight chickpea cultivars grown at five different locations and found a great effect of year, location and cultivars on different nutrient concentrations. They found a good range of magnesium, iron, selenium, copper, manganese and zinc in chickpea seeds; however, calcium was highly dependent on the type of cultivar. Hence, they highly emphasized on increasing the calcium content by selection process so that chickpea can efficiently supply dietary calcium. Similarly, Diapari et al., 2014 found considerable variability for iron and zinc concentrations in 94 chickpea accessions (including both desi and kabuli types) grown at two different sites. Among the screened accessions, three of their kabuli and two of their desi types were loaded with both highest Fe (more than 50 ppm) and Zn (more than $40 \mathrm{ppm}$ ) concentrations and hence, can be directly used as potential donors in breeding programs aiming for genetic biofortification. Torutaeva et al., 2014 estimated significant variability in protein and mineral content among 23 chickpea 
accessions representing Kyrgyz, Turkish and Spanish cultivars along with the ICARDA breeding lines. Protein content in studied accessions was wide ranging from $14.5 \%$ to $26.9 \%$, while concentrations for minerals were similar to those obtained by Thavarajah and Thavarajah, 2012.

Aliu et al., 2016 evaluated the chemical configuration of seven Kosovan chickpea genotypes grown in two consecutive years and revealed a wide range of variation. The mean protein, $\mathrm{Mg}, \mathrm{Ca}, \mathrm{Fe}$ and $\mathrm{Zn}$ content obtained in their study was $28.85 \mathrm{~g}$ per 100 g, $622.86 \mathrm{mg} \mathrm{kg}^{-1}, 347.17 \mathrm{mg} \mathrm{kg}^{-1}, 28.41 \mathrm{mg}$ $\mathrm{kg}^{-1}$ and $35.54 \mathrm{mg} \mathrm{kg}^{-1}$, respectively. In 2016, Upadhyaya et al., estimated the genetic variation for Iron and Zinc content among 92 desi and kabuli chickpea accessions grown at two varied geographical locations for two successive years. They found an average of 63.3 and $46.2 \mathrm{ppm}$ of $\mathrm{Fe}$ and $\mathrm{Zn}$, respectively. Additionally, they identified eight major QTLs participating in the regulation of chickpea seeds $\mathrm{Fe}$ and $\mathrm{Zn}$ content.

\section{Conclusion}

Most of the studies described in this short review revealed that both desi and kabuli chickpea cultivars possess sufficient amount of genetic variability for nutrient and protein content and can be effectively utilized in breeding programs. To our knowledge, none of the nutrient diversity analysis has been conducted on wild chickpea germplasm, that if conducted may provide a viable key for genetic biofortification of chickpea cultivars. Additionally, nutrients and protein rich cultivars identified in the mentioned nutrient diversity studies should be competently exploited by farmers, breeders and molecular biologists to develop enriched chickpea varieties.

\section{References}

Aliu S., Kaul, H.-P., Rusinovci, I., Shala-Mayrhofer, V., Fetahu, S., Zeka, D., 2016.Genetic diversity for some nutritive traits of Chickpea (Cicer arietinum L.) from different regions in Kosova. Turkish Journal of Field Crops, 21: 156-161.

Bohra, A., Sahrawat, K.L., Kumar, S., Joshi, R., Parihar A.K., Singh, U., Singh, D., Singh N.P., 2015. Genetics-and genomics-based interventions for nutritional enhancement of grain legume crops: status and outlook. Journal of Applied Genetics. 56: 151-161.

Bouis, H.E., Welch, R.M., 2010. Biofortification-a sustainable agricultural strategy for reducing micronutrient malnutrition in the global south. Crop Science, 50: 20-32.

Bueckert, R., Thavarajah, D., Thavarajah, P., Pritchard, J., 2011. Phytic acid and mineral micronutrient in field grown chickpea (Cicer arietinum L.) cultivars from western Canada. European Food Research and Technology, 233: 203-212.

Cakmak, I., Torun, A., Millet, E., Feldman, M., Fahima, T., Korol, A.B., Nevoe, E., Braunf, H.J., Ozkanb H., 2004.Triticumdicoccoides: an important genetic resource for increasing zinc and iron concentration in modern cultivated wheat. Soil Science and Plant Nutrition. 50: 1047-1054.

Caliskan S., Erdogan C., Arslan M., Caliskan M., 2013.Comparison of organic and traditional production systems in chickpea (Cicer arietinum L.). Turkish Journal of Field Crops. 18: 34-39.

Carvalho, S.M.P., Vasconcelos, M.W., 2013. Producing more with less: 'omics' at the service of plant-based food biofortification. Food Research International, 54: 961-971.

Chavan, J.K., Kadam, S.S., Salunkhe, D.K., 1989. Chickpea. In: Salunkhe, D.K., Kadam, S.S. (Eds.), CRC Handbook of World Food Legumes: Nutritional Chemistry, Processing Technology and Utilization, vol. I. CRC Press, Inc., Boca Raton, FL, USA, pp. 247-288.

Combs, G.F., Jr.;Welch, R.M., Duxbury, J.M., 1998. Fighting hidden hunger. The World \&। 1998, 4, 174-181. 
Diapari, M., Sindhu, A., Bett, K., Deokar, A.,Warkentin, T.D., Tar'an B., 2014. Genetic diversity and association mapping of iron and zinc concentration in chickpea (Cicer arietinum L.). Genome, 57: 459-468.

Duranti, M., Gius, C., 1997. Legume seeds: Protein content and nutritional value. Field Crops Research, 53: 31-45.

Dwivedi, S.L., Sahrawat, K.L., Rai, K.N., Blair, M.W., Andersson, M., Pfieffer, W., 2012. Nutritionally enhanced staple food crops. Plant Breeding Reviews, 34: 169262.

Ereifej, K.I., Al-Karaki, G.N., Hammouri, M.K., 2001. Seed chemical composition of improved chickpea cultivars grown under semiarid Mediterranean conditions. International Journal of Food Properties. 4: 239-246.

Food and Agriculture Organisation, International Fund for Agricultural Development \& World Food Program, 2015. The State of Food Insecurity in the World 2015.Meeting the 2015 International Hunger Targets: Taking Stock of Uneven Progress. Rome: FAO.

Godfray, H.C.J., 2010. Food security: the challenge of feeding 9 billion people. Science. 327: 812-818.

Graham, R.D., Welch, R.M., Bouis, H.E. 2001. Addressing micronutrient malnutrition through enhancing the nutritional quality of staple foods: principles, perspectives and knowledge gaps. Advances in Agronomy, 70: 77-142.

Haider, M., Haider, S., 1984.Assessment of protein-calorie malnutrition. Clinical Chemistry, 30: 1286-1299.

HarvestPlus, 2012. Retrieved from: http://www.harvestplus.org/ Accessed on July, 2012.

Hoekenga, O.A., 2014. Genomics of mineral nutrient biofortification: calcium, iron and zinc. In: Tuberosa R et al (eds) Genomics of plant genetic resources. Springer, Dordrecht, pp 431-454.

Hotz, C., Brown, K.H., 2004. Assessment of the risk of zinc deficiency in populations and options for its control. Food and Nutrition Bulletin, 25: S94-S204.

Ibrikci, H., Knewtson, S.J.B., Grusak, M.A., 2003. Chickpea leaves as a vegetable green for humans: evaluation of mineral composition. Journal of the Science of Food and Agriculture, 83: 945-950.
Iqbal, A., Khalil, I.A., Ateeq, N., Khan, M.S., 2006. Nutritional quality of important food legumes. Food Chemistry, 97: 331-335.

Jukanti, A., Guar, P., Gowda, C. L. L., Chibbar, R., 2012. Nutritional quality and health benefits of chickpea. British Journal of Nutrition, 108: S11-S26.

Kennedy, G., Nantel, G., Shetty P., 2003. The scourge of "hidden hunger": Global dimensions of micronnutrient deficiencies. Food Nutrition and Agriculture. 32: 8-16.

Mayer, J.E., Pfeiffer, W.H., Beyer, P. 2008. Biofortified crops to alleviate micronutrient malnutrition. Current Opinion in Plant Biology, 11: 166-170.

Monti, L.M., Grillo, S. 1983. Legume seed improvement for protein content and quality. Plant Foods for Human Nutrition, 32: 253-266.

Nestel, P., Bouis, H.E., Meenakshi, J.V., Pfeiffer, W. 2006. Biofortification of staple food crops. The Journal of Nutrition, 136: 10641067.

Niba L.L., 2003. The relevance of biotechnology in the development of functional foods for improved nutritional and health quality in developing countries. African Journal of Biotechnology, 2: 631-635.

Ozer, S., Karakoy, T., Toklu, F., Baloch, F.S., Kilian, B., Ozkan, H., 2010.Nutritional and physicochemical variation in Turkish kabuli chickpea (Cicer arietinum L.) landraces.Euphytica, 175: 237-249.

Petterson, D.S., Sipsas, S., Mackintosh, J.B., 1997. The chemical composition and nutritive value of Australian pulses.2nd ed. Grains Research and Development Corporation, Kingston, Australia.

Rana, A., Joshi, M., Prasanna, R., Shivay Y.S., Nain, L., 2012.Biofortification of wheat through inoculation of plant growth promoting rhizobacteria and cyanobacteria. European Journal of Soil Biology, 50: 118126.

Ray, H., Bett, K., Tar'an, B., Vandenberg, A., Thavarajah, D., Warkentin, T.D., 2014. Mineral micronutrient content of cultivars of field pea, chickpea, common bean, and lentil grown in Saskatchewan, Canada.Crop Science. 54: 1698-1708.

Sadanandan B., Channarayappa, 2014. The hidden hunger and strategies for its alleviation - A review. Journal of Nutrition Research, 2: 32-37. 
Sahin, N., Gecit, H.H., 2006. The effects of different fertilizing methods on yield and yield components in chickpea (Cicer arietinum L.). Journal of Agricultural Scientia, 12: 252-258.

Singh, U., Jambunathan, R., 1981. Studies on desi and kabuli chickpea (Cicer arietinum L.) cultivars: Levels of protease inhibitors, levels of polyphenolic compounds and in vitro protein digestibility. Journal of Food Science, 46: 1364-1367.

Thavarajah, D., Thavarajah, P., 2012. Evaluation of chickpea (Cicer arietinum L.) micronutrient composition: biofortification opportunities to combat global micronutrient malnutrition. Food Research International, 49: 99-104.

Tonk, F.A., E. Ilker, M. Tosun, 2010. A study to incorporate high protein content from tetraploid wheat (T. turgidumdicoccoides) to hexaploid wheat ( $T$. aestivum vulgare). Turkish Journal of Field Crops, 15: 69-72.

Torutaeva, E., Asanaliev, A., Prieto-Linde, M.L., Zborowska, A., Ortiz, R., Bryngelsson, T., Garkava-Gustavsson, L., 2014.Evaluation of microsatellite-based genetic diversity, protein and mineral content in chickpea accessions grown in Kyrgyzstan. Hereditas, 151: 81-90.

Tulchinsky, T.H., 2010. Micronutrient deficiency conditions: global health issues. Public Health Reviews, 32: 243-255.

Upadhyaya, H.D., Bajaj, D., Narnoliya, L., Das, S., Kumar, V., Gowda, C.L.L., Sharma, S., Tyagi, A.K., Parida, S.K., 2016.GenomeWide Scans for Delineation of Candidate Genes Regulating Seed-Protein Content in Chickpea.Frontiers in Plant Sciences.7: 302.doi: 10.3389/fpls.2016.00302

Welch, R. M., 2002. Breeding strategies for biofortified staple plant foods to reduce micronutrient malnutrition globally. The Journal of Nutrition, 132: 495S-499S.
Welch, R. M., Graham, R. D., 2004. Breeding for micronutrients in staple food crops from a human nutrition perspective.Journal of Experimental Botany. 55: 353-364.

Welch, R.M., 1999. Importance of seed mineral nutrient reserves in crop growth and development. In: Rengel Z, ed. Mineral nutrition of crops. Fundamental mechanisms and implications,. New York: Food Products Press, 205-226.

White, P.J., Broadley, M.R., 2005. Biofortifying crops with essential mineral elements. Trends in Plant Sciences, 10: 586-593.

White, P.J., Broadley, M.R., 2009. Biofortification of crops with seven mineral elements often lacking in human diets-iron, zinc, copper, calcium, magnesium, selenium and iodine. New Phytologist, 182: 49-84.

WHO, 2000.Guidelines on food fortification withmicronutrients for the control ofmicronutrient malnutrition. Geneva: World Health Organization. http://www.who.int/nutrition/publication s/micronutrients/GFF_Part_1_en.pdf?ua= 1.

Wood, J.A., Grusak, M.A., 2006. Nutritional value of chickpea.In Chickpea breeding and management. Edited by S.S. Yadav, R.J. Redden, W. Chen, and B. Sharma. Cromwell Press, Trowbridge, UK.

World Health Organization [WHO], 2013.Updates on the Management of Severe Acute Malnutrition in Infants, and Children. Geneva: World Health Organization

Zia-Ul-Haq, M., Iqbal, S., Ahmad, S., Imran, M., Niaz, A., Bhanger, M.I., 2007. Nutritional and compositional study of Desi chickpea (Cicer arietinum L.) cultivars grown in Punjab, Pakistan. Food Chemistry, 105: 1357-1363. 